\title{
Transformation Poem Nyanyian Angsa by W. S. Rendra to Novel Maria Zaitun by Joko Santoso: Intertextual Study
}

\author{
Nesya Yanmas Yara ${ }^{1}$, Sarwiji Suwandi ${ }^{2}$, Sumarwati ${ }^{3}$ \\ ${ }^{123}$ Postgraduate Education Indonesian Language FKIP Sebelas Maret University, Indonesia \\ Inesya_yara94@student.uns.ac.id,.2sarwijiswan@yahoo.com. \\ ${ }^{3}$ watik_uns@ymail.com
}

\begin{abstract}
The transformation of literary work today began to flourish in the field of literary studies, especially from novel to film form. The process of transformation on the form of poetry to other forms is still rare, but in this study researchers managed to find transformation from the poem Nyanyian Angsa by W. S. Rendra to novel Maria Zaitun by Joko Santoso. This research aims to describe the form of additions, substitutions, and differences in the poetry Nyanyian Angsa by W. S. Rendra and novel Maria Zaitun by Joko Santoso. The theory used in this study is transformation with qualitative descriptive research methods. The source of this research data is the poem text Nyanyian Angsa by W. S. Rendra and novel Maria Zaitun by Joko Santoso. Data collection techniques using reading techniques and note taking techniques, as well as interactive data analysis from Miles \& Huberman (1992). The results of this study showed that additions, substitutions, and differences from poetry to novels found similarities and differences. The difference is because the building elements of the two literary works are different, but overall the literary works have similarities.
\end{abstract}

Keyword : transformation; poetry; novels; additions; substitutions; differences.

\section{Introduction}

Changes in the form of works of different types previously referred to as transformations. It was evident from the many film directors flocking to create different versions of literary works such as novels. Recently a lot of transformations from the novel to the film made the beginning of the transformation of a masterpiece. The tendency to transform a novel into a movie is something new because both of them have the same element based on the story. The difference between the two lies in the processing of a story, it is because the novels and films have different medias. If the novel is mediate and the words, the film is mediate. The deeper tendency is if the novel has no limitations in its storytelling, while the film has a time limit or duration. The assumption was clarified by Nurgiyantoro (2007:18) explaining that transformation is a change in the aspect of the element, the content of a literary work, a linguistic like word and sentence.

Transformation is widely interpreted as a change, the exchange of one type to another. The transformation process resulted in a change, addition, reduction of the previous form of work. The existence of transformation by some researchers is not without reason, the most understandable reason by all parties is when the work is known to the world. Like the poem Nyanyian Angsa by a famous writer in Indonesia, namely W. S. Rendra. The poem has been included in the Blues Untuk Bonnie collection, who has become the best-selling poem used by literary researchers to become a research material.

There is a definition of Damono (2005:96) relating to the transformation of literary works that the changes can also be of one type of work. In addition, works can also be changed from one language to another with different types. Such an assessment can be beneficial to expand our minds, because literature can vary according to the development of an increasingly uncontrollable day. 
Transformation is an intertextual element that examines two literary genres. Intertextual is one of the assessments describing the literary phenomenon that is close to the reader. The reader's experience becomes very important to know the meaning of the text that has been read as a text that has relevance to the new text. According to Berthes (in Stead, 2009:21) Any text is a network derived from the past text then redistributed into a new text. In line with Berthes's opinion, Meinhof \& Smith (2000:3) that all texts contain traces of other texts with much more complex conceptions relating to the relationship between the previously existing text. The concept that emphasizes the intertextual assessment is that the text that is born is another text that can complement the later born text.

Speaking of text, the tranformation of a text occurs also in the text poem Nyanyian Angsa W. S. Rendra into a text written novel Maria Zaitun by Joko Santoso. Poetry is a literary genre that has the language density and sentence length used. This means that more and more focused forms of literary work than in a language expressed or spoken in colloquially are called poetry (Perrine in Siswantoro, 2010:23). In addition, the genre has a beauty in its usage that can be according to the theme of poetry. Pradopo (2010:5) Explains that poetry performs interpretations through rhythmic language. Poetry is also a form of expression of the author's idea for evoking feelings, stimulating imagination for readers or listeners.

The basic principle of poetry is to have a short sentence or a slight but dense number of words. Aminuddin (2011:134) argues that poetry is the expression of an author's feeling that contains a particular message relating to the physical or inner feelings of the author. Based on this, the novel text is totality as a whole, meaning that the novel has interconnected sections of one another. The elements in question are intrinsic and extracinsik elements. In a novel told of a variety of conflicting characters and one another, the long story makes the novel one of the literary works that is reckoned with other works. Smiley (2008:14) explains that the novel is a narrative-shaped inscription or description and contains conflicting stories between the one and the other characters.

Based on the exposure, the text of poetry with novel text has a natural relation. Therefore, researchers are interested in doing a poetry review with the novel, which is the review of the transformation between the poem Nyanyian Angsa by W. S. Rendra and the novel Maria Zaitun by Joko Santoso. This assessment has a focus on transformation based on the addition, replacement, and difference aspects of the poem Nyanyian Angsa with the novel Maria Zaitun While the purpose of conducting this assessment is to describe the transformation based on the aspects of addition, replacement, and difference. With the assessment, it is hoped to contribute in the field of literary studies, especially the transformation of literary works. For other readers or researchers, this study can dijadikani additional references in other studies relating to the transformation of literary works.

\section{Research Method}

The methods in this study are qualitative descriptive. Qualitative research is understood as a type of research in the form of descriptions. Qualitative research can be used as a research method on community life, social reality, social activity and others. The approach in this study uses content analysis with the aspect of the study of the transformation of the poem Nyanyian Angsa by W. S. Rendra to the novel Maria Zaitun by Joko Santoso. The content analysis is used in describing the contents of a poem text Nyanyian Angsa by W. S. Rendra and the novel Maria Zaitun by Joko Santoso. Fraenkel, Wallen, \& Hyna (2015) defines content analysis as 
an approach to studying human behaviour indirectly through their communication. Communication in the form of oral and written such as, textbooks, novels, poems, short stories, magazines, advertisements, pictures, articles, songs etc. that type of communication can be analyzed using content analysis.

The Data in the poetry Nyanyian Angsa by W. S. Rendra and the novel Maria Zaitun by Joko Santoso are words, sentences that correspond to the study in this research: additions, substitutions, and differences from poetry to novels. The source of this research data is the poetry of the Nyanyian Angsa by W. S. Rendra and the novel Maria Zaitun by Joko Santoso. Meanwhile, data collection techniques using Read and note-taking techniques. This research instrument is conducted by researchers. Researchers as instruments relate to text-oriented literary research traits. So, the required data will be created groups by researchers by reading and noting according to the formulation of research issues. Based on the problems and objectives of the research, data analysis in this study uses interactive that is done with data reduction, namely selecting data, summarizing, and creating classification. Further data presentation, and withdrawal of conclusion (Miles \& Huberman, 1992).

\section{Results and Discussion}

The poem of the Nyanyian Angsa by W. S. Rendra is a hipogram of the novel Maria Zaitun by Joko Santoso. The story presented from both literary works has an equation of the same, showing a story of the heartache of a despicated prostitute. The life lived by Maria Zaitun as a prostitute is not as smooth as her body skin. Test-by-exam always comes a change like being in line. The female figure of Maria Zaitun received various rejections, torture, discrimination, and instoration from a number of parties. Each of the authors laid down the incident as a prostitute of the capital. Injustice, arbitrariness accompany the journey of Maria Zaitun until the end of her life.

Through a story played by a female figure, especially a woman we can take such lessons, how one must remain steadfast in the bitterness of the world and be able to overcome all the problems of life. Based on the story's exposure to the poem Nyanyian Angsa by W. S. Rendra and novel Maria Zaitun by Joko Santoso with similarities and differences, researchers found transformations based on aspects of additions, substitutions, and differences proves that there has been a transformation process from both literary works. The following presentation of data descriptions and discussions according to the focus and purpose of the problem in this study:

\section{Transformation of the Poem Nyanyian Angsa by W. S Rendra to Novel Maria Zaitun Joko Santoso}

The changes are simply seen in the novel Maria Zaitun. In general, poetry has limitations in words that require the reader to understand deeply according to the content of the poem. When there is a process of transformation from poetry to novels, it is clearly seen that the structure between the two is very different. The differences of structure can be seen based on the form, the rules in the poetry, and of course the rules in the novel. In the making of poetry, the authors always use a solid, clear, concise language, accompanied by a very beautiful selection of words to make it happen with something beyond the linguistic that is used to communicate daily. It was done by the author to impress the poetry he presented has the power and that the message conveyed to the listener is acceptable. 
While speaking with regards to the novel, the presented story allows to complement each other a poem. If poetry has a solid language version, the novel is a long and more detailed one. So readers are easier to guess the picture of the theme, figure, Plot, background, etc. that correspond to the reader's imagination. The storyline that is conveyed through the novels will look understandable from poetry. The plot created by the author is tailored to the storyline. Therefore, the transformation from poetry to novels is unique and rare because of structural differences that make literary researchers have to always think extra to find themes, figures, grooves, backgrounds etc in poetry.

Based on the exposure with regards to aspects of poetry and novels, the results of transformation conducted by researchers in relation to the transformation of poetry to novels show changes. It certainly corresponds to the theory of transformation that there is additions, with the reference of the novel Maria Zaitun as the work of transformation. The additions contained in the novels of Maria Zaitun include, figures, settings, and orders. Then based on changes from poetry to novel covers, additions, substitutions, and differences. Furthermore, the equation is seen in the theme aspect showing the story of the main character of the Maria Zaitun, based on the fact that novel Maria Zaitun by Joko Santoso was a transformation from the poem of the Nyanyian Angsa by W. S Rendra. Below will be shown the discussion of research results obtained by researchers through the theory of transformation of poetry to novels, namely:

\title{
A. Addition
}

The poetry Nyanyian Angsa by W. S. Rendra tells a story of the life of a prostitute named Maria Zaitun who has a life of suffering. Maria Zaitun was a symbolic figure of the kink of a woman in the lead of a life of pain. As the poem's title is a disclosure used Nyanyian Angsa by W. S. Rendra to illustrate the life of Maria Zaitun. Geese is an animal that has a white fur color such as the self-depiction of an Maria Zaitun who has a sacred personality. The animals that when slaughtered were still able to walk here and shout despite the blood. It is an author like Maria Zaitun who remains firmly in his suffering. Walk here and find peace of life even though man is not friendly to him. The illustrated events reveal the anger, disappointment, the heartache of Maria Zaitun to her life. The feeling was accompanied by a steadfastness, independence, and sincerity from the character that later formed a character character in the novel Maria Zaitun by Joko Santoso. The expansion is described by the authors in the following quotation:

\author{
"Malaekat penjaga firdaus \\ wajahnya sombong dan dengki \\ dengan pedang yang menyala \\ menuding kepadaku \\ aku lesu tak berdaya. \\ Tak bisa menangis. Tak bisa bersuara. \\ Maria Zaitun namaku. \\ Pelacur yang lapar dan dahaga"
}

The addition of poetry to novels happens to figures, backgrounds, and orders. The addition of other figures that reinforce the story in the novel is Murni, Sherly, Doctors, Hertomo Prodjosoemantri, Nyi Roro Kidul, Kanjeng Sunan Kalijaga, Patih GajahMada, and Ki Kebo Iwa. These figures are the additions that make the story in the novel Maria Zaitun Complete, while in the poetry of the song the figure of the picture is very limited. 
Transformation on the next aspect of addition occurs in the background/setting. In the Maria Zaitun novel, the author adds a backdrop to the place and timing of events. If in the background of the swan song the setting shows only a few places. The addition of the Dimagsudkan background to clarify events occur in the story.

Then the transformation on the aspect of additions that last seen in the message aspect. The message in the book of Maria Zaitun with the message found in the poem Nyanyian Angsa looks the same that it must remain steadfast in the face of every problem and severity of life. The mandate in the novel of Maria Zaitun is that the addition of the element of the mandate is for men to treat a woman well, who must be respected, guarded, protected, and appreciated, especially if the woman is a life partner. Then other orders relate to the struggle of life, the struggle to find the way of life blessed by the Lord.

\section{B. Replacement}

In the transformation of the replacement aspect, in the poem Nyanyian Angsa, there are some events that clearly describe the story, but in the form of the transformation of novel Maria Zaitun, the picture is clearer. The replacement is a descriptive, a depiction of the figure. There is a depiction of a character concealed by the author in the poem Nyanyian Angsa. The character is the "bride" of Maria Zaitun, W. S. Rendra portrays the bride as the God who met the Maria Zaitun to serve as a lover, but her depiction is not real only at first glance. It is shown in the following quotation:

"Semula kusangka hanya impian

Bahwa hal ini bisa kualami.

Semula tak berani kuharapkan

Bahwa lelaki tampan seperti kau

Lewat dalam hidupku.

Dengan penuh penghargaan, lelaki itu memandang kepadanya.

"Siapakah namamu?" Maria Zaitun bertanya.

"Mempelai," jawabnya. "

While the depiction of the character "Bride" in the novel Maria Zaitun is depicted clearly by changing the figures and characters of the character, Nyi Roro Kidul, Kanjeng Sunan Kalijaga, Patih GajahMada, and Ki Kebo Iwa.

\section{Difference}

The latter aspect of the transformation relates to the distinction between the poem of the Nyanyian Angsa by W. S. Rendra and the novel Maria Zaitun by Joko Santoso. In the poem there are several differences, namely the element of additional figures in the novel (Murni, Sherly, obstetrician, Hertomo Prodjosoemantri, Nyi Roro Kidul, Kanjeng Sunan Kalijaga, Patih GajahMada, and Ki Kebo Iwa), the background in the poem gets In the novel (background such as the Las Vegas state, Cilacap City, Wonosobo City, Hotel, Restaurant, Café, Airport, Clinic, Church, Pantai Widarapayang Binangun, the island of the Coral Gulf of Bandung, white sand beach Nusakambangan), and the mandate Gaining additional in novels (Life struggles, humanity, and social relations).

The difference between the poetry Nyanyian Angsa by W. S. Rendra and the novel Maria Zaitun is a very natural distinction, given that between poetry and novels has different building elements and previous exposure is a Complete with regards to the transformation of a poem Nyanyian Angsa by W. S. Rendra to the novel Maria Zaitun by Joko Santoso. With regards to 
the transformation that occurs between poetry and novels, it can be said that the text of literary works, however, its type and shape, is essentially a set of other texts. The interconnectedness of these texts is ultimately the meaning of the reader.

Therefore, the understanding of the reader in relation to poetry and the understanding of readers in relation to novels on one story meaning can be the same or different. This is because when understanding the meaning of the story in the poem, the reader has been presented with a wide imagination, while if the understanding of the meaning of the story in the novel, the author has described clearly and manifestly. So it can be said that Joko Santoso Bhawa novel was a new work, as it has offered a clearer understanding to the reader.

Related research on the tranformation of poetry to novels, novels to movies has been done much, such as research conducted by Oktafiyani \&, Suseno et al (2017), Wibowo (2012), Agustina (2016), Isnaniah (2015), and Inda (2016). In general, the research done is to transform novels into movies. The results of the study were largely transformational aspects, figures, luminaries, grooves, backgrounds, storytelling techniques, age figures, and events. In line with this, that research with past research has similarities and differences. If past research largely transforms novels into films, but in this study, researchers found another transformation from poetry to novels.

\section{Conclusion}

The conclusion of this study was that there was a transformation From the poem Nyanyian Angsa by W. S. Rendra to the novel Maria Zaitun by Joko Santoso. In accordance with the theory of transformation that is addition, replacement, and difference, researchers find some things that correspond to the theory of transformation that is, 1) additions contained in the novel include, the addition of the character (Murni, Sherly, Doctors, Hertomo Prodjosoemantri, Nyi Roro Kidul, Kanjeng Sunan Kalijaga, Patih Gajahmada, and Ki Kebo Iwa), 2) replacement of the poem to the novel is the groom's male character, in the novel The character changed (Nyi Roro Kidul, Kanjeng Sunan Kalijaga, Patih Gajahmada, dan Ki Kebo Iwa), 3) The difference, the overall difference between the poetry of Geese and the novel Maria Zaitun is a natural difference, but in the novel there are differences in the aspects (such as the Las Vegas country, the city of Cilacap, the city Wonosobo, hotel, restaurant, café, airport, clinic, church, Beach Widarapayang Binangun, Island Majeti Coral Bay of Bandung, white sand beach Nusakambangan), and the mandate to get additional in the novel (Life struggle, humanity, and social relations).

\section{Acknowledgements}

My gratitude is to convey to the parties who have been involved in this research, such as the Supervisor and editorial team of BIRCU Journal. Hope and the prayer of researchers, hopefully this article contributes in the field of education, especially the field of literature study around the world.

\section{Reference}

Agustina, A. 2016. Transformasi Naskah Lakon Macbeth (1603-1607) Karya William Shakespeare ke Film Thore of Blood atau Kumonosu-Jo (1957) Karya Akira Kurosowa. Journal of Urban Society's Art. III.(1). 1-9. 
Aminuddin. (2011). Pengantar Apresiasi Karya Sastra. Jakarta: Sinar Baru Algensindo.

Damono, S. D., 2005. Pegangan Penelitian Sastra Bandingan. Jakarta: Pusat Bahasa, Depdiknas.

Fraenkel, J. R., Wallen, N. E. 2009. How to Design and Evaluate Research in Education. New York: McGraw-Hill Companies.

Inda, D. N. 2016. Adaptasi Novel Ronggeng Dukuh Paruk ke dalam Film Sang Penari: Sebuah Kajian Enkranisasi. Journal Aksara XXVIII. (1). 25-38.

Isnaniah, S. 2015. Ketika Cinta Bertasbih Transformasi Novel ke Film. Jurnal Ilmu Sastra dan Humaniora. V. (1). 23-35.

Meinhof, U. H., Smith, J. 2000. Intertextuality and the Media. New York: Manchesther University Press.

Miles, M. B. \& Huberman, A. M. 1994. Qualitative Data Analysis. London : Sage Publisher.

Nurgiyantoro, B. 2007. Teori Pengkajian Fiksi. Yogyakarta: Gadjah Mada University Press.

Oktafiyani, A., Suseno, Nuryatin, A. 2017. Transformasi Makna Simbolik Mihrab pada Novel ke Film dalam Mihrab Cinta Karya Habiburrahman El Shirazy: Kajian Ekranisasi. Jurnal Sastra Indonesia. IV. (3). 39-45.

Pradopo, R. D. 2010. Beberapa Teori Sastra, Metode Kritik, dan Penerapannya. Yogyakarta: Pustaka Pelajar.

Siswantoro. 2010. Metode Penelitian Sastra: Analisis Struktur Puisi. Yogyakarta: Pustaka Pelajar.

Smiley, J. 2008. 13 Ways Of Looking at The Novel. United States of America: Knopf Double day Publishing Group.

Stead, M. R. 2009. The Intertextualy of Zechariah. London: T\&T Clark.

Wibowo, P. N. H. 2012. Ande-ande Lumut: Adaptasi Folklore ke Teater Epic Brecth. Journal of Performing Arts. XIII.(1). 31-40. 